\title{
VIOLENT CRIMES AND ADVERSE CHILDHOOD EXPERIENCES IN YOUNG OFFENDERS AT BLITAR JUVENILE DETENTION CENTRE
}

\author{
Jessica Shirleen Wilona, Yusti Probowati Rahayu*), Ayuni \\ Faculty of Psychology, Universitas Surabaya \\ Jl. Raya Kalirungkut, Kampus UBAYA Tenggilis, Surabaya, Indonesia 60293 \\ ${ }^{*}$ Corresponding author \\ yustiprobowati@gmail.com
}

\begin{abstract}
Violent crimes yield to fear and unsafe feelings have been also done by children. The General Strain theory explained that violence was occurred due to the criminal coping of individuals, who experienced the situation of pressures that yield into anger which might be developed into violent behaviour. Adverse Childhood Experiences (ACE) is a form of pressure within the family that might contribute to criminal coping. This research was aimed at investigating the differences of ACE on violent crimes and non-violent crimes. Participants of this study were 58 out of 213 boy offenders aged 12-18 years old in the Juvenile Detention Center in Blitar. These participants were chosen by the accidental sampling method based on the type of cases, in which 28 boys were on violent crimes (robbery, child protection, murder, and beating), while 30 boys were on non-violent crimes (theft and drug abuses). The measurement used was the ACE scale, applied with some modifications. The reliability coefficient of the ACE scale was .843. Data were analysed using a non-parametric method, which was the Mann-Whitney U. The examination of mean rank and the effect size of this study showed that ACE was higher on violent crimes, even though this result was not supported by the hypothesis examination result, which was not significant $(U=3.47, p=.129)$. It could be concluded that ACE on the violent crimes group tended to be higher compared to the non-violent crimes group.
\end{abstract}

Keywords: Adverse childhood experiences; violent and non-violent crimes; Juvenile Detention Center in Blitar

\begin{abstract}
Abstrak
Kejahatan dengan kekerasan yang memunculkan rasa takut dan tidak aman dilakukan juga oleh anak-anak. Teori General Strain menjelaskan bahwa kekerasan muncul karena individu dengan criminal coping mengalami situasi menekan yang menimbulkan emosi marah sehingga memunculkan perilaku tersebut. Criminal coping sering kali terbentuk dari situasi menekan di keluarga, salah satunya berupa Adverse Childhood Experiences (ACE). Penelitian ini bertujuan untuk mengetahui perbedaan ACE pada kejahatan dengan kekerasan dan tanpa kekerasan. Partisipan adalah 58 dari 213 anak didik laki-laki berusia 12-18 tahun di Lembaga Pembinaan Khusus Anak (LPKA) Blitar, dipilih dengan accidental sampling berdasarkan kasus: 28 orang pada kelompok kekerasan (perampokan, perlindungan anak, pembunuhan, dan pengeroyokan), serta 30 orang pada kelompok tanpa kekerasan (pencurian dan narkotika). Alat ukur yang digunakan adalah alat ukur ACE yang dimodifikasi dari alat ukur ACE asli dengan reliabilitas 0,843 , kemudian dianalisis menggunakan uji beda non-parametrik Mann-Whitney $U$. Uji mean rank dan effect size pada penelitian ini menunjukkan ACE lebih tinggi pada kelompok kekerasan, walau tidak didukung uji hipotesis yang tidak signifikan $(U=347, p=0,129)$. Hal ini berarti ada kecenderungan skor ACE pada kelompok kejahatan dengan kekerasan lebih tinggi dibanding kelompok kejahatan tanpa kekerasan.
\end{abstract}

Kata kunci: Adverse childhood experiences; kejahatan dengan dan tanpa kekerasan; LPKA Blitar

\section{INTRODUCTION}

The children's case facing the law is a crucial issue in Indonesia. The annual report of the National Commission of Child Protection (NCCP; Komisi Perlindungan Anak Indonesia
[KPAI]) in 2018 shows 19,843 complaint cases, which increased in the last four years. In 2015 there was an increase in child protection cases totalling 4,309; in 2016, there were 4,622 cases, 2017 it totalled 4,579 cases, and in 2018 it reached 4,885 cases. From the total number of 
reported issues submitted to NCCP, children facing the law showed the largest percentage, $29 \%$ or 5,372. Children facing the law (CFL) cases in Indonesia have increased every year, as happened in the last four years. In 2015 the number of reported CFL cases reached 1,221 children, in 2016, there were 1,314. In 2017 there were 1,403 reported cases, and in 2018, there were 1,434 issues (NCCP in Fauziyah, Suryanto, \& Rahayu, 2019). The suspect child is called a child in conflict with the law (Fauziyah et al., 2019). Law number 11 of 2012 regarding the Criminal Justice System for Children (CJSC) states that children in conflict with the criminal law will undergo ordinary criminal justice and be accommodated in Juvenile Detention Centre (JDC; Lembaga Pembinaan Khusus Anak [LPKA]) if they are sentenced to more than seven years or if the diversion process is unsuccessful. Several studies explain that population, unemployment, number of industries, and poverty levels are the causes of crime (Lumenta, Kekenusa, \& Hatidja, 2012). This study will discuss the causes of crime from a psychological perspective.

In article 89 of the Criminal Code, violent crimes are described as crimes that make a person helpless or weak, including passed (Handoko, 2018). The US Department of Justice (2016) defines violent crimes as offences and threat which involve force (attack, coercion, or threats), such as murder and nonnegligent manslaughter, rape, robbery, and aggravated assault. Violent crimes are caused by several factors, namely: (a) psychological or biological abnormalities, (b) human instincts, (c) substance abuse, (d) socialization and upbringing, (e) exposure to violence, (f) and cultural values or violent subcultures (Siegel, 2012). Points $d, e$, and $f$ are factors that have a significant risk of forming violent behaviour, especially when experienced in childhood. Jonson-Reid, Kohl, and Drake (2012) conducted a longitudinal study from 1993 to 2009 on 3,521 children (aged 1.5 to 11 years) who came from low socioeconomic status and experienced child maltreatment. The result explained that chronic child maltreatment could harm subsequent development. Research by Jung, Herrenkohl, Klika, Lee, and Brown (2015) showed that $78 \%$ of participants who experienced child maltreatment had committed at least one crime, $46 \%$ of participants who had experienced childhood maltreatment had been detained.

Adverse Childhood Experiences (ACE) is a childhood event that can cause trauma or stress and can lead to negative physical, mental, and behavioural health problems (Fagan \& Novak, 2018). Reavis, Looman, Franco, and Rojas (2013) examined ACE in 151 participants who experienced child abuse (non-sexual), domestic violence, sexual harassment, and stalkers. That study shows that participants experienced four times the ACE when compared to adult males from the normative sample. The research result by Fox, Perez, Cass, Baglivio, and Epps (2015) suggests ACE as a significant direct predictor of serious, violent, chronic (SVC) delinquency in young people. Perez, Jennings, and Baglivio (2018) provide similar results. Wolff, Baglivio, and Piquero (2017) also found a relationship between ACEs and recidivists. Some situations considered as adverse childhood experiences according to WHO (2011) are: physical, emotional, sexual abuse, the family member with alcohol and drug abuse, detained or imprisoned family members, family members with depression, mental illness, suicidal thoughts, or family member who are included in a social institution, have violent experiences, have only one or no parents, have divorced parents, are emotionally and physically neglected, experience bullying, witness violence in the community and are exposed to war or collective violence.

Using the perspective of general strain theory, children under 18 years of age who experience $\mathrm{ACE}$ are under stress. These pressures give rise to negative emotions. Children having no 
coping ability or the ability to deal with stressful events tend to develop criminal behaviour as a form of coping behaviour. According to Agnew (2008), certain negative emotions might be associated with certain criminal behaviour. Maltreatment is positively associated with state anger (Gao, Wong, \& Yu, 2016). An example of how anger is relevant to the emergence of violence is an increase of the desire for revenge, justification of the wrongdoings with the belief to fix/correct what's considered as wrong, and encouragement to commit the criminal behaviour.

The discussion above shows a link between $\mathrm{ACE}$ and the emergence of criminal behaviour, particularly with violence. Research on adverse childhood experiences in Indonesia is still limited because most of the researchers emphasize child maltreatment in children with no relation to child crime (Choiriyah, 2015; Novianti, Febrialismanto, \& Puspitasari, 2018). This study aims to prove that children's ACE score in JDC with violent crimes is higher than non-violent crimes.

\section{METHOD}

This quantitative survey research on 58 students in Juvenile Detention Centre Blitar used an accidental sampling technique to obtain the participants. Participants were boys aged 12-18 years and divided into two groups based on the crime type: violent and non-violent crimes. The participant distribution into the groups is based on the Criminal Code article suspected to the participants, violent and non-violent crimes. The mean age is 16.97 , and the $S D$ of the age is .99. Table 1 shows the articles and the number of participants.

Table 1.

Number of Participants

\begin{tabular}{|c|c|c|c|c|c|}
\hline \multirow{2}{*}{ No. } & \multirow{2}{*}{ Law } & \multirow{2}{*}{ Crimes } & \multicolumn{2}{|c|}{ Classification } & \multirow{2}{*}{$n$} \\
\hline & & & $\mathrm{VC}$ & NVC & \\
\hline 1 & Criminal code article 363 & Theft & - & $\checkmark$ & 6 \\
\hline 2 & Criminal code article 365 & Robbery & $\checkmark$ & - & 15 \\
\hline 3 & Law No. 35/2014 & $\begin{array}{l}\text { Crimes against child } \\
\text { protection }\end{array}$ & $\checkmark$ & - & 6 \\
\hline 4 & Law No. 35/2009 & Narcotics & - & $\checkmark$ & 24 \\
\hline 5 & Law No. 36/2009 & $\begin{array}{l}\text { Crimes against law of } \\
\text { health (drugs) }\end{array}$ & - & $\checkmark$ & - \\
\hline 6 & Criminal code article 340 & Murder & $\checkmark$ & - & 4 \\
\hline 7 & Criminal code article 285 & Rape & $\checkmark$ & - & - \\
\hline 8 & Criminal code article 351 & Persecution & $\checkmark$ & - & - \\
\hline 9 & Criminal code article 170 & Beating & $\checkmark$ & - & 3 \\
\hline & & Total & & & 58 \\
\hline
\end{tabular}

Note $. \mathrm{VC}=$ Violent Crimes $; \mathrm{NVC}=$ Non-violent Crimes.

The research team provided a modification of the ACE questionnaire from Felitti et al. (Sacks, Murphey, \& Moore in Fagan \& Novak, 2018). The modifications are made by adjusting to the children situation, like adding the word caregiver. There are nine aspects of ACE: emotional abuse, physical abuse, sexual harassment, emotional neglect, physical neglect, domestic violence, substance abuse in the household, family members with mental disorders, and detained/ imprisoned family members. The number of ACE items is 18, an example of the items is: "your parent/caregiver abuses you" (hitting, slapping, kicking, etc.). Participant filled out the questionnaire in group. There are seven to 10 young offender in each 
session, and the research team provided the instruction. The number of participants was uncertain in each session because the place/ location for data collection and the conditions during data collection were less conducive and unpredictable. The validity and reliability test shows that the measuring instrument is valid and reliable with a total-item correlation score range of .184 to .747 and a reliability coefficient of .843. The data analysis used was the nonparametric test of comparison, Mann-Whitney $U$, because the data distribution is not normal.

\section{RESULTS AND DISCUSSION}

The following table is a description of participants in the violent crimes group and non-violent crimes group with their characteristics and the results of crosstabulation of age at first crime, education level, and recidivist status. The results of this description provide an overview of the participants and explain the following discussion results.

Most of the participants were at the age of 17 for both violent and non-violent crimes. They are mostly graduated from elementary school or junior high school. Among non-violent offenders, drug problems are the most frequent cases, while the most frequent cases in violent offenders are robbery. The majority committed their first violation at the age of 16 , committed violations in groups, and came from Surabaya.

Table 2.

Demographic Characteristics and Case Profiles

\begin{tabular}{|c|c|c|c|c|c|c|c|c|}
\hline \multirow{2}{*}{ No. } & \multirow{2}{*}{ Characteristic } & \multirow{2}{*}{ Category } & \multicolumn{2}{|c|}{ NVC } & \multicolumn{2}{|c|}{$\mathrm{VC}$} & \multicolumn{2}{|c|}{ Samples } \\
\hline & & & $n$ & $\%$ & $N$ & $\%$ & $n$ & $\%$ \\
\hline \multirow{6}{*}{1.} & \multirow{6}{*}{ Age } & 15 & 1 & 3.3 & 1 & 3.6 & 2 & 3.4 \\
\hline & & 16 & 9 & 30 & 8 & 28.6 & 17 & 29.3 \\
\hline & & 17 & 10 & 33 & 15 & 53.6 & 25 & 43.1 \\
\hline & & 18 & 8 & 26.7 & 2 & 7.1 & 10 & 17.2 \\
\hline & & 19 & 1 & 3.3 & 2 & 7.1 & 3 & 5.2 \\
\hline & & 20 & 1 & 3.3 & 0 & 0 & 1 & 1.7 \\
\hline \multirow{4}{*}{2.} & \multirow{4}{*}{ Last education } & $\begin{array}{l}\text { Not completed } \\
\text { primary school }\end{array}$ & 2 & 6.7 & 2 & 7.1 & 4 & 6.9 \\
\hline & & Primary school & 12 & 40 & 11 & 39.3 & 23 & 39.7 \\
\hline & & Junior high school & 12 & 40 & 13 & 46.4 & 25 & 43.1 \\
\hline & & Senior high school & 4 & 13.3 & 2 & 7.1 & 6 & 10.3 \\
\hline \multirow{6}{*}{3.} & \multirow{6}{*}{ Crimes } & Narcotics & 24 & 80 & 0 & 0 & 24 & 41.4 \\
\hline & & Theft & 6 & 20 & 0 & 0 & 6 & 10.3 \\
\hline & & Beatings & 0 & 0 & 3 & 10.7 & 3 & 5.2 \\
\hline & & Robbery & 0 & 0 & 15 & 53.6 & 15 & 25.9 \\
\hline & & $\begin{array}{l}\text { Crimes against } \\
\text { child protection }\end{array}$ & 0 & 0 & 6 & 21.4 & 6 & 10.3 \\
\hline & & Murder & 0 & 0 & 4 & 14.3 & 4 & 6.9 \\
\hline \multirow{2}{*}{4.} & \multirow{2}{*}{ Recidivist/ not } & First time & 27 & 90 & 23 & 82.1 & 50 & 86.2 \\
\hline & & Recidivist & 3 & 10 & 5 & 17.9 & 8 & 13.8 \\
\hline \multirow{2}{*}{5.} & \multirow{2}{*}{ Partner } & No partner & 4 & 13.3 & 5 & 17.9 & 9 & 15.5 \\
\hline & & With partner & 26 & 86.7 & 23 & 82.1 & 49 & 84.5 \\
\hline
\end{tabular}


Table 2.

(Continued)

\begin{tabular}{|c|c|c|c|c|c|c|c|c|}
\hline \multirow{6}{*}{6.} & \multirow{6}{*}{$\begin{array}{l}\text { Age at first } \\
\text { offense }\end{array}$} & 12 & 1 & 3.3 & 0 & 0 & 1 & 1.7 \\
\hline & & 13 & 2 & 6.7 & 0 & 0 & 2 & 3.4 \\
\hline & & 14 & 1 & 3.3 & 0 & 0 & 1 & 1.7 \\
\hline & & 15 & 4 & 13.3 & 6 & 21.4 & 10 & 17.2 \\
\hline & & 16 & 14 & 46.7 & 13 & 46.4 & 27 & 46.6 \\
\hline & & 17 & 8 & 26.7 & 9 & 32.1 & 17 & 29.3 \\
\hline \multirow{8}{*}{7.} & \multirow{8}{*}{$\begin{array}{l}\text { Length of } \\
\text { sentence }\end{array}$} & $<7$ months & 2 & 6.7 & 0 & 0 & 2 & 3.4 \\
\hline & & 7 months $-<1$ year & 1 & 3.3 & 4 & 14.3 & 5 & 8.6 \\
\hline & & $1-<2$ years & 15 & 50 & 6 & 21.4 & 21 & 36.2 \\
\hline & & $2-<3$ years & 7 & 23.3 & 11 & 39.3 & 18 & 31 \\
\hline & & $3-<4$ years & 2 & 6.7 & 1 & 3.6 & 3 & 5.2 \\
\hline & & $4-<5$ years & 1 & 3.3 & 1 & 3.6 & 2 & 3.4 \\
\hline & & 5 - 10 years & 2 & 6.7 & 4 & 14.3 & 6 & 10.3 \\
\hline & & $>10$ years & 0 & 0 & 1 & 3.6 & 1 & 1.7 \\
\hline \multirow{2}{*}{8.} & \multirow{2}{*}{$\begin{array}{l}\text { Previous offense } \\
\text { (although not } \\
\text { imprisoned) }\end{array}$} & Yes & 13 & 43.3 & 15 & 53.6 & 28 & 48.3 \\
\hline & & No & 17 & 56.7 & 13 & 46.4 & 30 & 51.7 \\
\hline \multirow{8}{*}{9.} & \multirow{8}{*}{ First offense age } & 7 & 2 & 6.7 & 0 & 0 & 2 & 3.4 \\
\hline & & 11 & 1 & 3.3 & 0 & 0 & 1 & 1.7 \\
\hline & & 12 & 1 & 3.3 & 0 & 0 & 1 & 1.7 \\
\hline & & 13 & 2 & 6.7 & 1 & 3.6 & 3 & 5.2 \\
\hline & & 14 & 3 & 10 & 1 & 3.6 & 4 & 6.9 \\
\hline & & 15 & 4 & 13.3 & 5 & 17.9 & 9 & 15.5 \\
\hline & & 16 & 8 & 26.7 & 14 & 50 & 22 & 37.9 \\
\hline & & 17 & 9 & 30 & 7 & 25 & 16 & 27.6 \\
\hline
\end{tabular}

Note. $\mathrm{NVC}=$ Non-violent Crimes; $\mathrm{VC}=$ Violent Crimes .

Table 3.

Age of First Offense and ACE

\begin{tabular}{ccccc}
\hline \multirow{2}{*}{ Category } & Low & Moderate & High & Total \\
& $f(\%)$ & $f(\%)$ & $f(\%)$ & $f(\%)$ \\
\hline 7 & $0(0)$ & $0(0)$ & $2(100)$ & $2(100)$ \\
11 & $1(100)$ & $0(0)$ & $0(0)$ & $1(100)$ \\
12 & $1(100)$ & $0(0)$ & $0(0)$ & $1(100)$ \\
13 & $3(100)$ & $0(0)$ & $0(0)$ & $3(100)$ \\
14 & $3(75)$ & $1(25)$ & $0(0)$ & $4(100)$ \\
15 & $9(100)$ & $0(0)$ & $0(0)$ & $9(100)$ \\
16 & $18(81.8)$ & $4(18.2)$ & $0(0)$ & $22(100)$ \\
17 & $15(93.8)$ & $1(6.2)$ & $0(0)$ & $16(100)$ \\
\hline Total & $50(86.2)$ & $6(10.3)$ & $2(3.4)$ & $58(100)$ \\
\hline
\end{tabular}

Chi-square cross-tabulation shows a significant negative correlation between first offence age and $\operatorname{ACE} \chi^{2}(14, N=58)=62.297, p=.0001$. All participants aged seven have ACE scores in the high category, while 11 to 17 have ACE scores in the low and moderate category. The younger 
the age of the first offence, the higher the ACE score (Table 3 ), these results are consistent with the findings of Baglivio, Wolff, Piquero, and Epps (2015).

Erikson explained that at the age of seven, individuals have just started the learning stage of functioning in a broader social sphere than in the family context (Weiten, 2013). This development stage will be problematic if the development tasks in the previous stages have not been fulfilled. Unfulfilled emotional development stages cause stress (Ahsan \& Ilmy, 2018). According to Piaget (Weiten, 2013), the cognitive development of a 7-year-old child is between the end of the preoperational stage and the beginning of the concrete operational stage. The child is unable to think abstractly, including the impact of behaviour reviewed from various perspectives. Children will find it easier to imitate the behaviour he sees at home, react to ACE at home, and cope with emotional conditions based on the coping strategies he learned at home without looking further the impact of these behaviours. In general, until seven, children interact more in the family, so the effect of ACE is higher. Meanwhile, between 11 and 17 years of age, children's interactions with their peers begin to play an essential role in their lives.

The chi-square cross-tabulation test shows a positive correlation between recidivist status with the ACE score with $\chi^{2}(2, N=58)=21.669$, $p=.0001$ (Table 4). Table 3 shows that only two recidivists show the high ACE score; three are in a low category, and others in the moderate category. There are no high ACE scores in nonrecidivist participants. The low compared to middle score is 47 to 3 , with a percentage of 94\%. The higher the ACE score, the higher the likelihood of recurring crime. These results are consistent with the research of Baglivio et al. (2016), which shows an indirect relationship between ACE and recidivism. Research by Wolff, Baglivio, and Piquero (2017) suggests a high prevalence that someone with ACE tends to become a recidivist in a shorter period. Wolff and Baglivio (2017) show that ACE directly or indirectly affects recidivism, and nearly half of the total effect involves negative emotions. Another study found that young people with higher ACE scores were significantly more likely to be recaptured earlier within one year (Wolff, Baglivio, \& Piquero, 2017).

Table 4.

Recidivist Status and ACE

\begin{tabular}{lcccc}
\hline Category & Low & Moderate & High & Total \\
& $f(\%)$ & $f(\%)$ & $f(\%)$ & $f(\%)$ \\
\hline First time & $47(94)$ & $3(6)$ & $0(0)$ & $50(100)$ \\
Recidivist & $3(37.5)$ & $3(37.5)$ & $2(25)$ & $8(100)$ \\
\hline Total & $50(86.2)$ & $6(10.3)$ & $2(3.4)$ & $58(100)$ \\
\hline
\end{tabular}

The "accumulation theory" mentioned by Linsky and Straus (in Agnew, 1992) explains that stressful situations which occurred over a short span of time can significantly impact a person compared to a specific event's effect. The results of these situations can be additive or interactive. Additive means that each stressor has a particular effect on juvenile delinquency. Interactive means that previous individuals' stressful situations can lead to higher distress when facing stressful situations in the future. Research discussing this topic is still limited, but according to this view, certain levels of stressful situations must arise to produce a negative behaviour outcome. In this case, the history of having been in JDC or JDC background can be a pressure for children when they re-enter the community. The stigma from society becomes pressure that increases distress due to ACE situations, both, inside and outside 
the family. This situation triggers certain emotions; meanwhile, these children's coping strategies are still the same as before entering JDC. This situation can cause the recurring of violent and nonviolent crimes. $53.6 \%$ of participants in violence cases had committed violations before, while in cases without violence, $43.3 \%$. The violent group shows a more significant number of recidivists than the non-violent group.

Chi-square cross-tabulation describes the negative correlation between education level and ACE with $\chi^{2}(6, N=58)=16.027, p=.014$. Participants who did not complete primary school and graduated from primary school have high ACE scores. In participant with junior high school educational background, $88 \%$ has low and $12 \%$ moderate scores. All high school graduate participants have low ACE scores (Table 5). These results indicate that the higher the level of education, the lower the ACE score and vice versa. According to Kitchener and King (1981), individuals with higher education can think complexly and considering many behavioural reasons. Participants with higher educational backgrounds have a broader perspective, including assessing the reasons of caregivers' behaviour. In that case, they might not perceive the violent behaviour of the caregiver as ACE but as an expression of love and care to educate them.

Table 5.

Last Education and ACE

\begin{tabular}{lcccc}
\hline \multirow{2}{*}{ Last Education } & Low & Moderate & High & Total \\
& $f(\%)$ & $f(\%)$ & $f(\%)$ & $f(\%)$ \\
\hline Not completed primary school & $1(25)$ & $2(50)$ & $1(25)$ & $4(100)$ \\
Primary School & $21(91.3)$ & $1(4.3)$ & $1(4.3)$ & $23(100)$ \\
Junior High School & $22(88)$ & $3(12)$ & $0(0)$ & $25(100)$ \\
Senior High School & $6(100)$ & $0(0)$ & $0(0)$ & $6(100)$ \\
\hline Total & $50(86.2)$ & $6(10.3)$ & $2(3.4)$ & $58(100)$ \\
\hline
\end{tabular}

Table 6 demonstrates the Mann-Whitney $U$ test result, which shows that the result is not significant $(U=347, p=.129)$. The mean difference was not far between the two groups (Table 7), with most ACE scores at the low and moderate level (Table 8).

Table 6.

Hypothesis Test Results

\begin{tabular}{lccc}
\hline Variable and Aspect & M-W $U$ & $p$ (one-tailed) & Description \\
\hline Adverse Childhood Experiences & 347 & .129 & Not significant \\
Emotional Abuse & 415 & .466 & Not significant \\
Physical abuse & 392 & .323 & Not significant \\
Sexual abuse & 406.5 & .403 & Not significant \\
Emotional neglect & 332 & .066 & Not significant \\
Physical neglect & 337.5 & .072 & Not significant \\
Domestic violence & 353 & .114 & Not significant \\
Household Substance Abuse & 402 & 390 & Not significant \\
Family Members with Mental Illness & 416.5 & .129 & Not significant \\
Family members who are detained/imprisoned & 415.5 & .471 & Not significant \\
Note. M-W $U=$ Mann-Whitney $U$. & & & \\
\hline
\end{tabular}


Table 7.

Description of the Score of Adverse Childhood Experiences

\begin{tabular}{lccc}
\hline Category & Violent Crimes & Non-violent Crimes & $n$ \\
\hline Highest score & 60 & 76 & 76 \\
Lowest score & 18 & 18 & 18 \\
$M(S D)$ & $32.21(9.78)$ & $30.77(13.47)$ & $31.47(11.76)$ \\
\hline
\end{tabular}

Table 8.

Categorization Score of Adverse Childhood Experiences

\begin{tabular}{|c|c|c|c|c|}
\hline Category & Limit Value & $\begin{array}{c}\text { Violent Crimes } \\
f(\%)\end{array}$ & $\begin{array}{c}\text { Non-violent Crimes } \\
f(\%)\end{array}$ & $\begin{array}{l}\text { Sample } \\
f(\%)\end{array}$ \\
\hline High & $X \geq 66$ & - & $2(6.7)$ & $2(3.4)$ \\
\hline Moderate & $42 \leq X<66$ & $5(17.9)$ & $1(3.3)$ & $6(10.3)$ \\
\hline Low & $\mathrm{X}<42$ & $23(82.1)$ & $27(90)$ & $50(86.2)$ \\
\hline Total & & $28(100)$ & $30(100)$ & $58(100)$ \\
\hline
\end{tabular}

Even though the result is not significant, this study finds the difference in the effect size and the mean rank between the two groups (Table 9). In five of nine aspects, the violent crimes group's ACE score appears to be higher than the non-violent group (Table 10). The five aspects are emotional neglect $(d=3.06)$, physical neglect $(d=2.93)$, domestic violence $(d=2.36)$, physical abuse $(d=1.05)$, family members with mental disorders $(d=.94)$.

Table 9.

Effect-size Test Result

\begin{tabular}{lcccc}
\hline Variable and Aspect & $\begin{array}{c}\text { VC Mean } \\
\text { Rank }\end{array}$ & $\begin{array}{c}\text { NVC Mean } \\
\text { Rank }\end{array}$ & $\begin{array}{c}\text { Standardized } \\
\text { Effect-size }\end{array}$ & Size \\
\hline Adverse Childhood Experiences & 32.1100 & 27.0700 & .447819 & Small \\
Emotional Abuse & 29.3200 & 29.6700 & -.20841 & Small \\
Physical abuse & 30.5000 & 28.5700 & 1.045791 & Large \\
Sexual abuse & 29.9800 & 29.0500 & .39434 & Small \\
Emotional neglect & 32.6400 & 26.5700 & 3.062195 & Large \\
Physical neglect & 32.4500 & 26.7500 & 2.934182 & Large \\
Domestic violence & 31.8900 & 27.2700 & 2.364719 & Large \\
Household Substance Abuse & 28.8600 & 30.1000 & -.42402 & Small \\
Family members who are imprisoned & 29.3400 & 29.6500 & -.09536 & Small \\
Family Members with Mental Illness & 29.6300 & 29.3800 & .935414 & Large \\
\hline
\end{tabular}

Note $. \mathrm{VC}=$ Violent Crimes; $\mathrm{NVC}=$ Non-violent Crimes.

Table 10.

Mean Rank Ratio

\begin{tabular}{lccc}
\hline Variable and Aspect & VC Mean Rank & NVC Mean Rank & $d$ \\
\hline Adverse Childhood Experiences & 32.11 & 27.07 & 5.04 \\
Emotional abuse & 29.32 & 29.67 & .35 \\
Physical abuse & 30.5 & 28.57 & 1.93 \\
Sexual abuse & 29.98 & 29.05 & .93 \\
Emotional neglect & 32.64 & 26.57 & 6.07 \\
\hline
\end{tabular}


Table 10.

(Continued)

\begin{tabular}{lccc}
\hline Physical neglect & 32.45 & 26.75 & 5.7 \\
Domestic violence & 31.89 & 27.27 & 4.62 \\
Household substance abuse & 28.86 & 30.1 & 1.24 \\
Family members with mental illness & 29.63 & 29.38 & .25 \\
Family members who are imprisoned & 29.34 & 29.65 & .31 \\
\hline
\end{tabular}

Note $. \mathrm{VC}=$ Violent Crimes; $\mathrm{NVC}=$ Non-violent Crimes; $d=$ Difference.

Although not supported by the Mann-Whitney $U$ test results, this research finds the difference in mean rank and effect size, indicating a difference in ACE scores in the two groups. Different scores exist on emotional neglect, physical neglect, domestic violence, physical abuse, family members with mental disorders. This finding is in line with the research' result of Fagan and Novak (2018), which stated that $\mathrm{ACE}$ is related to the emergence of violence in black participants. Perez et al. (2018) and Fox et al. (2015) suggest that ACE is a significant direct predictor of Serious, Violent, and Chronic (SVC) delinquency. Dierkhising et al., Fox et al., as well as Loeber and Farrington (Fox et al., 2015) also support that compared to nonSVC criminals, most SVC perpetrators are victims of trauma, violence, neglect, and maltreatment during childhood.

Based on the General Strain Theory (GST), stressful situations can generate negative emotions that influence a person's behaviour in forming criminal coping. One of the criteria for developing criminal coping is the absence of the ability to perform conventional coping that is normative, good, and normal. The factor that differentiates the two crime groups is the emotional factor. Emotions that appear in violence cases are anger that leads to a desire to revenge, justify behaviour for correcting bad behaviour, and strengthen the violent behaviour. Continuous stressful situations can cause emotional traits and even form high criminal coping (Agnew, 1992).

Factors influencing human development are social, family and psychology. Bartol and Bartol (2014) explain several risk factors for criminal behaviour: developmental, biological, learning, and situational. Biological factors include genetic, physiology, pregnancy and birth conditions, hormones and neurotransmitters, executive function and the brain's parts involved in problem-solving. Learning and situational factors are related to expectations, positive consequences, modelling, perceptions, competencies, and specific circumstances experienced by individuals, such as frustration. The risk factors are related to one another. The study results of Baglivio and Epps (2016) found the relationship between ACE of the participants who experienced one ACE, $67.5 \%$ reported being exposed to four or more additional ACEs, and $24.5 \%$ to 6 or more additional ACEs. The psychological development of the individual is closely related to biological factors and their development. The five aspects of ACE show that children are exposed to violence both as victims and witnesses of violence. It also indicates that the family does not function properly and cannot fulfil the children's needs, such as security, care, and control.

According to Sahler and Carr (2009), modelling is one way to form a coping strategy. In other words, exposure is a learning and situational factor. Children imitate the way parents and caregivers behave and solve problems. They learn and use the coping strategy from their parents to deal with specific situations. Children can also have expectations to have positive consequences by imitating parents' behaviour. They may not understand, not aware, and not able to see the direct or indirect consequences of their behaviour, such as dealing with the 
police, being arrested. Mills et al. (2011) explain an association between experiencing neglect and abuse with perceptual considerations in children. For children with immature cognitive abilities, exposure to violence can cause adaptation to violent behaviour. In facing the problems, and they are in a state of anger, they imitate and create a coping strategy from their experience.

Carr (2006) states that parents or caregivers' important role in the family is to form routines to meet the need for security, attention, and control. Parents' attention helps adolescents in good social problem solving (Bahirah, Agustin, Setyowati, \& Imaroh, 2019). Parenting failure can cause emotional difficulties, especially in managing anger and frustration in children. If the failure is irrevocable, the risk of developing a conduct disorder increases. Family dysfunction can affect children's psychological development in terms of cognition and selfregulation. Children who experience emotional neglect, physical neglect, and physical abuse indicate a failure of the family function in meeting affective needs (Carr, 2006). Nasrudin (2013) found a significant relationship between family affective function and emotional intelligence in adolescents. The lack of completion of affection needs within the family is one of the causes of children seeking affection and acceptance outside the family, especially in adolescence.

The data in this study indicated that the participants in the violence group violated the law at the age of $15(21.4 \%), 16(46.4 \%)$, and $17(32.1 \%)$ years at the time they entered adolescence (Table 2). According to Weiten (2013), the influence of peers in adolescence is enormous. So, it is not surprising that $82.1 \%$ of the participants in this study violated the law together with their friends. The friendly environment with the delinquent subculture encourages children to commit crimes as a form of conformity (Esiri, 2016; Fitriani \& Hastuti, 2016). Bartol and Bartol (2014) explain the learning factor. Children learn that by engaging in some criminal behaviour, they can have positive consequences such as increased status among peers, self-esteem, capable and competent, tense sensations, and perceiving the sensations as positive consequences. Lack of control in the family is also one of the factors that cause difficulties for children to follow the rules and regulate their emotions, so they are prone to use violence for their coping strategies. Even more, if they adopt coping strategy from their family and environment. Agnew (1992) states that delinquent behaviour arises when the behaviour is associated with the person who drives the behaviour to be executed, becomes a behaviour model, and becomes a determinant of children's value.

This study found one aspect that has an effect size and a higher mean rank difference in the violence group, and it is the family members with mental disorders. ACE does not explain mental disorders further, but the history of mental disorders in the family suggests that someone may have similar matters, like genes that influence a person's antisocial behaviour. McDermott, Tingley, Cowden, Frazzetto, and Johnson (in Bartol \& Bartol, 2014) explained that genes underlie behaviour patterns, one of which is monoamine oxidase $\mathrm{A}$ (MAOA) which influences antisocial behaviour. This gene is not an absolute determinant of the emergence of criminal action because the environment also plays an important role. Research by Fergusson, Boden, Horwood, Miller, and Kennedy shows that individuals with low-activity MAOA variant who experienced childhood trauma significantly more liable to report offending in their late adolescence and early adulthood period (Bartol \& Bartol, 2014). Toth, Harris, Goodman, and Cicchetti explained that biologically, children could experience an allostatic response that plays a role in generating anger and violent crime in certain situations (Fox et al., 2015). Individuals with self-regulation or emotion-regulation problems will find difficulties in controlling their 
emotions, especially anger. So, they tend to commit violent crimes, learned from homes, peers, and their environment as a form of coping. Meanwhile, emotional intelligence can reduce delinquency or juvenile crime behaviour (Garvin, 2017).

There are several factors that influence the result of Mann-Whitney $U$ analysis not proven as significant: the small sample size, the limitation of the self-inventory questionnaire, and the bias of classifying violent and nonviolent crimes. The ACE self-inventory measurement instrument is not suitable for students in JDC because of the children's low educational background. Most of the participants could not complete elementary school and junior high school graduates (Table 2). Educational background can influence the understanding of the fulfilment of the ACE measurement instrument. Second, there was high social desirability. An individual will tend to choose statements that should be selected or are considered following the norms prevailing in society (Tourangeau \& Yan, 2007). The bias trend in grouping violent and non-violent offenders can also influence the research results. The group's classification is based on the Criminal Code articles using legal terms, which may be different from psychological terms. According to the Criminal Code article, the perpetrators are included in the non-violent group, but they have committed violence in reality.

\section{CONCLUSION}

The results of this study indicate that there are differences in ACE scores between the two groups, the results of the effect size test are large, and there are differences in the mean rank in five of the nine aspects of ACE. The ACE score in the violent crimes group is higher than the non-violent crimes group. This research's theoretical implication is that ACE in the violence group is higher than the non-violent group. Besides, this study proves that family is an essential factor in shaping children's behaviour, including negative behaviour, such as crimes with violence. Violent behaviours might be developed by the presence of ACE through biological mechanisms, developmental, learning, and situational factors. Moreover, ACE relates to recidivist status, first offence age, and education. Several factors that influence this study's results are the small sample size, the limitation of the ACE as a measuring instrument for JDC students, and the bias of classifying violent and non-violent crimes. The description above shows the need for further research, which pays more attention to 1) the use of ACE measuring instruments: researchers suggest using ACE qualitatively as an interview guide, then use the results as a ground for concluding answers, and the researcher can score the answers quantitatively. 2) Control of situational factors: additional open-ended questions will increase control over situational factors, namely consideration of the criminal behaviour causes. Thus, the role of ACE in criminal behaviour will become increasingly apparent. 3) Conducting the test to see the score difference between children in JDC and children outside JDC. Another interesting topic for further research is the age at the first violation of the law, status (recidivist/first offence), and education level. The practical implication of this study is providing evidence of the fatal risk of ACE. It can impact family awareness to provide a secure environment for the children.

\section{REFERENCES}

Agnew, R. (1992). Foundation for a general strain theory of crime and delinquency. Criminology, 30(1), 47-87. doi: 10.1111/j.1745-9125.1992.tb01093.x

Agnew, R. (2008). General strain theory: Current status and directions for further research. In F. T. Cullen, J. P. Wright, \& K. R. Blevins (Eds.). Taking stock the status of 
criminological theory (pp. 101-123). London: Transaction Publishers.

Ahsan, A., \& Ilmy, S. A. (2018) Hubungan antara pemenuhan tugas perkembangan emosional dengan tingkat stres pada remaja. Jurnal Kesehatan Mesencephalon, 4(1), 152-156. 10.36053/mesencephalon.v4i1.70

Baglivio, M. T., \& Epps, N. (2016). The interrelatedness of adverse childhood experiences among high-risk juvenile offenders. Youth Violence and Juvenile Justice, 14(3), 179-198. doi: $10.1177 / 1541204014566286$

Baglivio, M. T., Jackowski, K., Greenwald, M. A., \& Howell, J. C. (2014). Serious, violent, and chronic juvenile offenders: A statewide analysis of prevalence and prediction of subsequent recidivism using risk and protective factors. Criminology \& Public Policy, 13(1), 83-116. doi: 10.1111/17459133.12064

Baglivio, M. T., Wolff, K. T., Piquero, A. R., Bilchik, S., Jackowski, K., Greenwald, M. A., \& Epps, N. (2016). Maltreatment, child welfare, and recidivism in a sample of deepend crossover youth. Journal of Youth and Adolescence, 45(4), 625-654. doi: 10.1007/s10964-015-0407-9

Baglivio, M. T., Wolff, K. T., Piquero, A. R., \& Epps, N. (2015). The relationship between adverse childhood experiences (ACE) and juvenile offending trajectories in a juvenile offender sample. Journal of Criminal Justice, 43(3), 229-241. doi:10.1016/j.jcrimjus.2015.04.012

Bahirah, A., Agustin, R. W., Setyowati, R., Imaroh, T. S. (2019). Peran regulasi emosi dan perhatian orang tua pada social problem-solving remaja yang bersekolah asrama. Indonesian Journal of Educational
Counseling, 3(2), 139-146. doi: $10.30653 / 001.201932 .88$

Bartol, C. R., \& Bartol, A. M. (2014). Criminal behavior: A psychological approach. New Jersey, NJ: Pearson Education.

Carr, A. (2006). Family therapy: Concepts, process, and practice. Chichester: John Wiley \& Sons.

Choiriyah, D. W. (2015). Systematic literature review on disrupting intergenerational transmission of child maltreatment. Proyeksi: Jurnal Psikologi, 10(1), 22-38. http://dx.doi.org/10.30659/p.10.1.22-38

Esiri, M. O. (2016). The influence of peer pressure on criminal behaviour. Journal of Humanities and Social Science, 21(1), 0814. doi: 10.9790/0837-21130814

Fagan, A. A., \& Novak, A. (2018). Adverse childhood experiences and adolescent delinquency in a high-risk sample: A comparison of white and black youth. Youth Violence and Juvenile Justice, 16(4), 395417. doi: 10.1177/1541204017735568

Fauziyah, N., Suryanto, \& Rahayu, Y. P. (2019) Resiliensi anak yang berkonflik dengan hukum: Refleksi implementasi UU. No.11 tahun 2012 mengenai proses diversi. AlDaulah: Jurnal Hukum dan Perundangan Islam, $\quad 9(2), \quad 194-221 . \quad$ doi: 10.15642/ad.2019.9.2.194-221

Fox, B. H., Perez, N., Cass, E., Baglivio, M. T., \& Epps, N. (2015). Trauma changes everything: Examining the relationship between adverse childhood experiences and serious, violent, and chronic juvenile offenders. Child Abuse \& Neglect, 46, 163173. doi: $10.1016 /$ j.chiabu.2015.01.011

Gao, Y., Wong, D. S. W., \& Yu, Y. (2016). Maltreatment and delinquency in China: 
Examining and extending the intervening process of general strain theory. International Journal of Offender Therapy and Comparative Criminology, 60(1), 3861. doi: 10.1177/0306624X14547495

Garvin, G. (2017). Kecerdasan emosi sebagai prediktor kecenderungan delinkuensi pada remaja. Jurnal Muara Ilmu Sosial, Humaniora, dan Seni, 1(1), 145-151. doi: 10.24912/jmishumsen.v1i1.344

Handoko, D. (2018). Kitab Undang-undang Hukum Pidana (h. 22). Pekanbaru: Penerbit Hawa dan Ahwa. Retrieved from https://books.google.co.id/books?hl=en\&lr $=\& \mathrm{id}=\mathrm{iOuIDwAAQBAJ} \& o \mathrm{i}=\mathrm{fnd} \& \mathrm{pg}=\mathrm{PR} 5$ $\& d q=k i t a b+u n d a n g+u n d a n g+h u k u m+p i d a n$ a\&ots=hjv5pv_Fmp\&sig=3RId2CIBFcm9f gPEYfKgqWk-

TMk\&redir_esc $=\mathrm{y} \# \mathrm{v}=$ onepage $\& \mathrm{q}=\mathrm{kitab} \%$ 20undang\%20undang\%20hukum\%20pidan $\mathrm{a} \& \mathrm{f}=$ false

Jonson-Reid, M., Kohl, P. L., \& Drake, B. (2012). Child and adult outcomes of chronic child maltreatment. Pediatrics, 129(5), 839845. doi: 10.1542/peds.2011-2529

Jung, H., Herrenkohl, T. I., Klika, J. B., Lee, J. O., Brown, E. C. (2015). Does child maltreatment predict adult crime? Reexamining the question in a prospective study of gender differences, education, and marital status. Journal of Interpersonal Violence, 30(13), 2238-2257. doi: $10.1177 / 0886260514552446$

Kitchener, K. S., \& King, P. M. (1981). Reflective judgment: Concepts of justification and their relationship to age and education. Journal of Applied Developmental Psychology, 2(2), 89-116. doi: 10.1016/0193-3973(81)90032-0

Lumenta, C. Y., Kekenusa, J. S., \& Hatidja, D. (2012). Analisis jalur faktor-faktor penyebab kriminalitas di kota Manado. Jurnal Ilmiah Sains, 12(2), 77-83. doi: 10.35799/jis.12.2.2012.556

Mills, R., Alati, R., O'Callaghan, M., Najman, J. M., Williams, G. M., Bor, W., \& Strathearn, L. (2011). Child abuse and neglect and cognitive function at 14 years of age: Findings from a birth cohort. Pediatrics, 127(1), 4-10. doi: 10.1542/peds.2009-3479

Nasrudin, N. (2013). Hubungan fungsi afektif keluarga terhadap kecerdasan emosional remaja. Jurnal EduHealth, 3(2), 89-96. http://journal.unipdu.ac.id:8080/index.php/ eduhealth/article/view/329

Novianti, R., Febrialismanto, F., \& Puspitasari, E. (2018, January). Child maltreatment perform by mother in Kepulauan Meranti Regency. Proceedings of the UR International Conference on Educational Sciences (pp. 566-570). Pekanbaru, Indonesia.

Perez, N. M., Jennings, W. G., \& Baglivio, M. T. (2018). A path to serious, violent, chronic, delinquency: The harmful aftermath of adverse childhood experiences. Crime \& Delinquency, 64(1), 3-25. doi: 10.1177/0011128716684806

Reavis, J. A., Looman, J., Franco, K. A., \& Rojas, B. (2013). Adverse childhood experiences and adult criminality: How long must we live before we possess our own lives? The Permanente Journal, 17(2), 44-48. doi: 10.7812/TPP/12-072

Sahler, O. J. Z., \& Carr, J. E. (2009). Coping strategies. In W. B. Carey, A. C. Crocker, W. L. Coleman, E. R. Elias, \& H. M. Feldman (Eds.), Developmental-Behavioral Pediatrics (pp. 491-496). doi: 10.1016/B978-1-4160-3370-7.00050-X 
Siegel, L. J. (2012). Criminology. Belmont, CA: Wadsworth Cengage Learning.

Tourangeau, R., \& Yan, T. (2007). Sensitive questions in surveys. Psychological Bulletin, 133(5), 859. doi: 10.1037/00332909.133.5.859

U.S. Department of Justice. (2016). Violent crime. Retrieved from https://ucr.fbi.gov/crime-in-theu.s/2016/crime-in-the-u.s.-2016/topicpages/violent-crime

Weiten, W. (2013). Psychology: Themes and variations. Belmont, CA: Wadsworth Cengage Learning.

Fitriani, W., \& Hastuti, D. (2016). Pengaruh kelekatan remaja dengan ibu, ayah, dan teman sebaya terhadap kenakalan remaja di Lembaga Pembinaan Khusus Anak (LPKA) Kelas II Bandung. Jurnal Ilmu Keluarga \& Konsumen, 9(3), 206-217. doi: 10.24156/jikk.2016.9.3.206

Wolff, K. T., \& Baglivio, M. T. (2017). Adverse childhood experiences, negative emotionality, and pathways to juvenile recidivism. Crime \& Delinquency, 63(12), 1495-1521.

doi:

$10.1177 / 0011128715627469$

Wolff, K. T., Baglivio, M. T., \& Piquero, A. R. (2017). The relationship between adverse childhood experiences and recidivism in a sample of juvenile offenders in communitybased treatment. International Journal of Offender Therapy and Comparative Criminology, 61(11), 1210-1242. doi: $10.1177 / 0306624 X 15613992$

World Health Organization. (2011). Adverse childhood experiences international questionnaire. Retrieved from http://www.who.int/violence_injury_ prevention/violence/activities/adverse_chil dhood_experiences/global_research_netwo rk_may_2011.pdf 